\title{
British Medical Association
}

\section{Annual Meeting at Melbourne}

$\mathrm{T}$ $\mathrm{HE}$ one hundred and third annual meeting of the British Medical Association was held in Melbourne, Australia, during the week commencing September 9, under the presidency of Sir James Barrett of Melbourne. This is the first occasion on which the Association has met in Australia. In spite of its remoteness from the Old World, the meeting was one of the largest, if not actually the largest, in the history of the Association. The total number of registered attending members was nearly 1,500 ; and there were more than 300 overseas visitors. Of the many distinguished visitors from Great Britain may be mentioned Lord Horder, Sir James Purves. Stewart, Sir Thomas Dunhill, Sir Ewen Maclean, Sir William Willcox, Sir Henry Gauvain, Prof. Edwin Bramwell, Prof. Hey Groves, Prof. A. M. Drennan, Mr. H. S. Souttar, Dr. J. S. Fairbairn, Dr. Robert Hutchison, Dr. S. Watson Smith (the retiring president), Dr. E. Kaye le Fleming and Dr. E. W. Fish. Members of the Association from South Africa, Egypt, India, Ceylon, Canada, New Zealand, Holland, China and Japan were present.

The adjourned annual general meeting took place on September 10 in the Town Hall, in the presence of Their Excellencies the Governor General of the Commonwealth, Sir Isaac Isaacs, and Lady Isaacs, and His Excellency the Governor of Victoria, Lord Huntingfield, and Lady Huntingfield. The principal events of the meeting were - an opening address by Sir Isaac Isaacs; induction of the new president, Sir James Barrett, who delivered his presidential address on the subject of hospital policy in Australia ; the transmission to His Majesty the King of a message of loyalty from the Association, to which a reply was received before the meeting ended; and presentation of the flag of the City of Melbourne to the Association by the Lord Mayor.

A meeting of the Royal Australasian Colloge of Surgeons took place on. September 12, under the presidency of Mr. R. B. Wade. Honorary fellowships were conferred on Prof. Hey Groves and Mr. H. S. Souttar ; and Prof. Hey Groves delivered the first Hamilton Russell Memorial Oration, entitled "The Romance of Surgery".

Before describing the discussions of the scientific sections, it is appropriate to mention the 'museum' which was housed in the University Anatomy School. The remarkably comprehensive and beautifully displayed collection was assembled specially for the occasion by a committee of which Prof. F. Wood Jones was chairman and Dr, E. S. J. King secretary. The exhibits embraced almost the entire range of human pathology as well as certain aspects of anthropology, parasitology, radiology and public health. Many of the exhibits were designed to form an illustrative accompaniment to some of the sectional discussions. On four mornings during the week, demonstrations of special subjects in the museum were given by the exhibitors.

The Section of Medicine, presided over by Lord Horder, discussed obesity, anæmia, and, on the third day in conjunction with the Section of Surgery, thyreotoxicosis. Other subjects dealt with in occasional papers were diabetic gangrene, hæmolytic jaundice and gallop rhythm of the heart. The most interesting discussion was that on thyreotoxicosis along with the surgeons, a meeting which had an attendance of nearly six hundred, easily a record for a sectional meeting. Lord Horder and Sir Thomas Dunhill opened the discussion. The principal point emerging, and one which was particularly stressed by Lord Horder, was that the pathogenesis of thyreotoxicosis is still unknown, and that the beneficial results of thyroidectomy do not necessarily justify the conclusion that the condition is one of primary thyroid dysfunction.

The Section of Surgery, with Sir Thomas Dunhill as president, discussed hydatid disease, the surgery of the pancreas, prostatectomy, cancer of the colon, and, along with the Section of Medicine, thyreotoxicosis. Apart from the last, the most notable debate was that on hydatid disease, opened by Prof. H. R. Dew. Almost all aspects of this subject were em. braced in the course of the discussion; which was well supplemented by the excellent collection of specimens of hydatid lesions and the life-history of Tonia echinococcus which were available for study in the special museum already described.

The Section of Obstetries and Gynaecology, under the presidency of Dr. J. S. Fairbairn, discussed Cæsarean section, placenta prævia, the late toxæmias of pregnancy, and the remote results of puerperal sepsis. With respect to Cæsarean section, there was a decided opinion, voiced particularly by Dr. J. Bright Banister, that this operation was often too lightly undertaken without adequate reason, and that there was need of careful formulation of the indications justifying the operation.

The Section of Radiology and Radio-Therapeutics, with Mr. H. M. Moran presiding, discussed radiation treatment of cancer of the breast and of cancer of the tongue, radiological diagnosis of diseases of the lung, diagnosis of bone tumours, radiological education and skiagraphic examination of the stomach and duodenum. The work of the section was well supplemented and enhanced in value by a series of skia grams illustrating the several subjects, which were displayed in the museum. The discussion on the diagnosis of bone tumours, opened by Dr. H. R. Sear, was of particular interest, as it emphasised the importance of recognising various types of metastatic tumours which might simulate primary tumours of bones.

The Section of Diseases of Children, with Dr. Robert Hutchison as president, discussed hare lip, infant feeding, pink disease and intussusception. The discussion on pink disease, opened by Drs. A. J. and I. J. Wood, provided a very complete epitome of existing knowledge of this illness, the pathogenesis of which is, however, still unknown.

The Section of Neurology and Psychological Medicine was presided over by Prof. Edwin Bramwell. Its first session was devoted to a consideration of the diagnosis, prognosis and treatment of brain tumours fifty years ago, and now. Prof. Bramwell's opening paper on this topic provided an excellent 
survey of the growth of our clinical knowledge of brain tumours. Advance has come principally through the use of special methods of clinical investigation, from the introduction of the ophthalmo scope up to our present-day use of such methods as ventriculography and encephalography. The second session of the section discussed the psychoses of adolescence, and the malarial treatment of nourosyphilis, the latter subject being illustrated by exhibits in the museum.

The Section of Ophthalmology, under the presidency of Dr. A. J. Ballantyne, discussed glaucoma, false binocular projection and abnormal retinal correspondence, idiopathic cyclitis and several minor subjects. On all the topics, the discussions were of considerable interest, and contained original work or ideas.

The Section of Orthopædics, presided over by Prof. Hey Groves, discussed fractures of the neck of the femur, osteoarthritis of the hip and knee, fractures of the spine, and the role of physiotherapy in orthopædic practice.

The Section of Oto-Rhino-Laryngology, under Mr. F. Muecke, considered maxillary and nasal sinusitis, chronic suppurative otitis media, sphenoidal sinusitis in relation to the pituitary gland and actinotherapy in laryngeal tuberculosis.

The Section of Pathology and Bacteriology was presided over by Prof. A. M. Drennan. At its first session various aspects of pathological calcification and bone disease were discussed, the principal paper being one on the pathology of osseous tissue by Prof. Drennan. A paper on leukæmic infiltrations was read by Prof. J. B. Cleland; and one on the neural components of teratomata, by Dr. R. A. Willis, this being amplified by photographs and maps exhibited in the museum. The second meeting of the section was largely devoted to bacteriology. A discussion on anærobes in disease was opened by Prof. H. A. Woodruff with an informative paper on anærobic infections in animals; and Dr. F. M. Burnet introduced a discussion on virus diseases, stressing the frequent occurrence of mild, but immunising, attacks of these and other infections. A new method of hæmoglobin estimation, based on the formation of globin picrate, was described by Dr. Bolliger.

The Section of Pharmacology, Therapeutics and Anæsthesia, under the presidency of Sir William
Willcox, discussed hypnotic drugs, urinary antiseptics, premedication and basal narcosis, gas anæsthesia, and spinal anæsthesia ; and Prof. W. A. Osborne contributed a paper on a vaso-constrictor principle in the frog's skin.

The Section of Public Medicine, under Sir Henry Gauvain as president, dealt with tuberculosis, industrial and tropical medicine, and racial problems. At its first meeting the subject of pleural effusion in artificial pneumothorax was introduced by an informative paper by Dr. D. B. Rosenthal ; and $\mathrm{Mr}$. M. P. Susman opened a discussion on tuberculous empyæma. At the second meeting of the section, which was combined with the Section of Medical Sociology, the principal subject was racial pressure problems in Australia and its neighbourhood, opened by Sir R. W. Cilento.

The Section of Medical Sociology, with Dr. E. Kaye le Fleming as president, discussed the Australian medical aerial services, the social aims of mental hygiene, and along with the Section of Public Medicine, racial pressure problems opened by Sir Raphael Cilento. Sir James Barrett spoke of the difficulties of agricultural and pastoral activity in the Northern Territory, pointing out that on parts of the south coast of Java, which has a population of forty million people, areas resembling northern Australia are reported to be practically empty, and that for successful agriculture a rainfall of at least ten inches in the dry season is essential. Sir James Barrett then quoted an article by Mr. Wynne Williams, from the last number of the Economic Record, to the effect that apart from Queensland, Northern Australia is economically incapable of carrying a large population of any race. The difficulty is not physiological but entirely economic.

The Section of Dermatology was presided over by Dr. S. Watson Smith. The principal subject for discussion was the incidence of skin diseases in Australia, opened by Dr. Herman Lawrence. A main point brought out was the exceptionally high incidence in Australia of keratosis, rodent ulcer and epithelioma-called by Dr. Lawrence the "epithelial triad" and attributed by him largely to sunlight. An account of staphylococcal skin infections by Dr. Ivan Connor indicated the value of treatment by toxoids. Dr. J. C. Belisario contributed a paper on fungus infections.

\section{Lumière and the Invention of Cinematography}

\begin{abstract}
A BRILLIANT gathering took place on the evening of November 6 at the Sorbonne, in honour of M. Louis Lumière, father of the cinema and of many other inventions in the field of photography.

The great hall of the University of Paris was resplendent with high officials, including the French President, M. Lebrun, the Diplomatic Corps, distinguished academicians and representatives of numerous scientific and industrial organisations.

M. Mario Roustan, Minister of Education, presided, and speakers vied with each other in paying tribute to the qualities which have enabled M. Lumière to devote half a century of an active and fruitful life to promote applied science.
\end{abstract}

M. Armbruster, president of the Renaissance Française, who took the initiative in organising the celebrations, supplied a historical outline. $\mathrm{He}$ mentioned how Lumière, son of a photographer, of Besançon, developed with his brother a successful manufacturing photographic plant at Lyons, which became known throughout the world. He recalled the first public presentation, on December 28, 1895, of moving pictures in the basement of a Paris café, at $14 \mathrm{bd}$. des Capucines, amidst much scepticism and sarcasm-which, however, did not prevent the rapid success and growth of the enterprise.

M. Ch. Fabry, the distinguished physicist, spoke of the numerous applications of Lumière's work. M. Ch. Delac quoted figures to show the great 